\title{
Syphilitic gastritis: a rare presentation of secondary syphilis
}

\author{
Mohammed Osman, ${ }^{1}$ Saqib Hasan, ${ }^{2}$ Qazi Azher, ${ }^{1}$ Mamoon Elbedawi, ${ }^{3}$ \\ Ghassan Bachuwa ${ }^{1}$
}

${ }^{1}$ Hurley Medical Center, Flint, Michigan, USA

${ }^{2}$ Department of Infectious Disease, Hurley Medical Center, Flint, Michigan, USA

${ }^{3}$ Gastroenterology Department, Hurley Medical Center, Michigan State University, Michigan, USA

\section{Correspondence to} Dr Ghassan Bachuwa, gbachuw2@hurleymc.com

Accepted 22 February 2018

\section{DESCRIPTION}

A 55-year-old woman presented to the hospital with vomiting and epigastric pain for 3 weeks and coffee-ground vomitus for 1 day. She reported $6 \mathrm{~kg}$ of weight loss over a 1-month period. The patient had been sexually active with the same male partner for the past 20 years but reported her partner to be promiscuous. Physical examination was remarkable for epigastric tenderness. CT of the abdomen showed mural thickening of the stomach (figure 1). Upper endoscopy showed erythema and friable mucosa with nodularity (figure 2).Multiple biopsies revealed gastric syphilis with interstitial metaplasia, and immunostaining showed numerous Treponema pallidum (figures 3 and 4). Rapid plasma reagin (RPR) titre was 1:128 (normal: non-reactive). The patient received one dose of intramuscular penicillin G 2.4 million units and reported full resolution of her symptoms on 3 months' follow-up. Repeat RPR titre 3 months after treatment was 1:32, repeat upper endoscopy at the same time showed resolved inflammation and absent T. pallidum on staining. The patient tested negative for HIV.

Involvement of the stomach by syphilis during the secondary phase has been described since the 18th

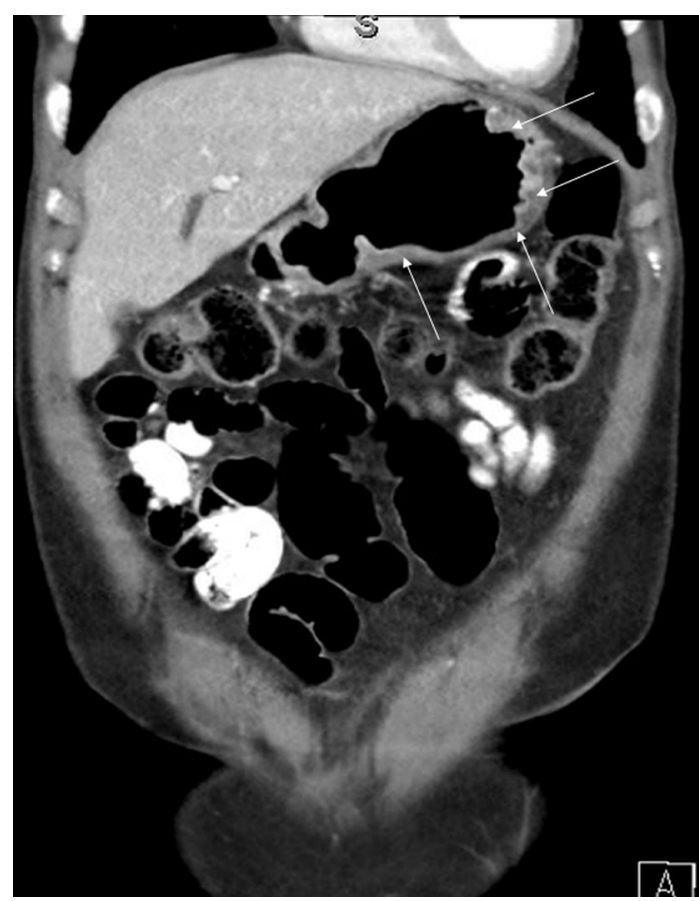

Figure 1 Coronal section of abdominal CT showing diffuse mural thickening of the stomach wall (white arrows).

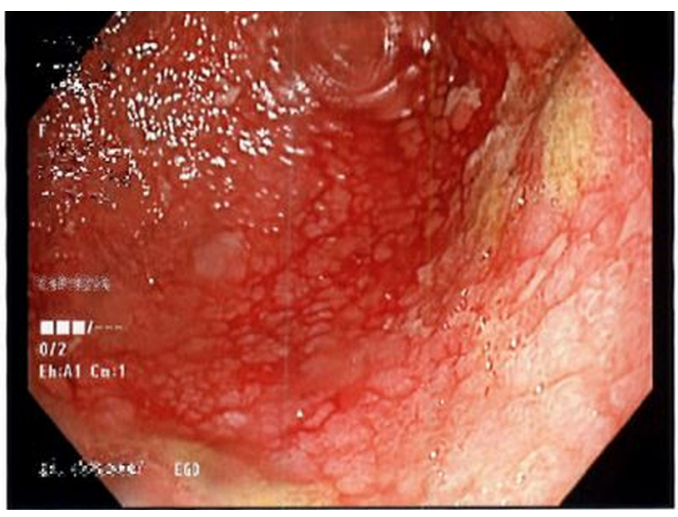

Figure 2 Upper endoscopy showing erythema, nodularity and friable mucosa of the stomach.

century, with the first two cases described in 1834 . Due to the rarity of the disease and the non-specific symptoms and signs, it is not well recognised by many
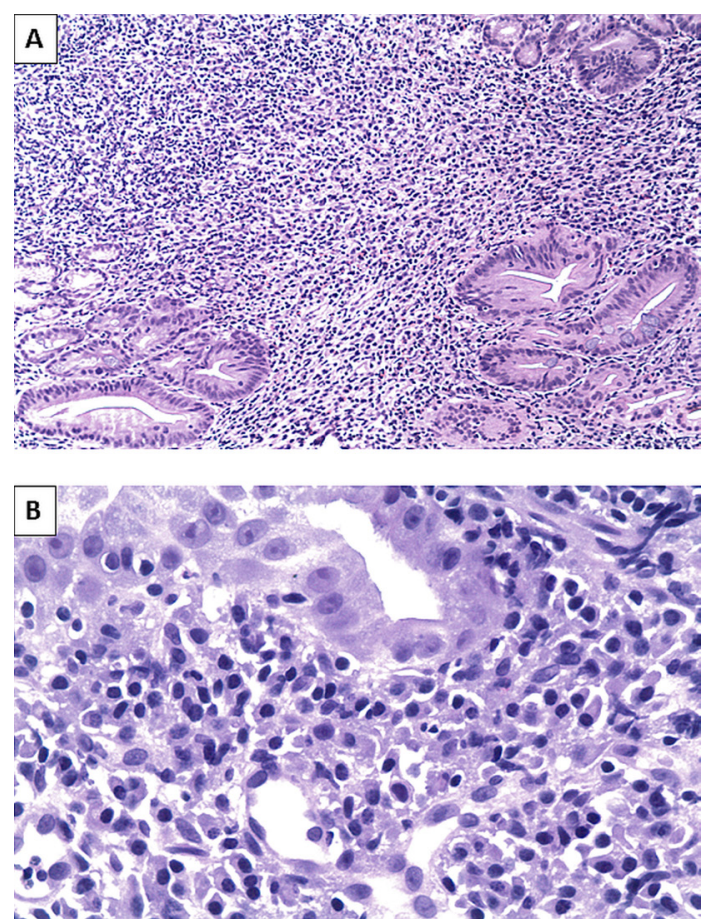

Figure 3 (A) Gastric mucosa with chronic inflammatory changes consisting of lymphocytes and plasma cells in the lamina propria. Reactive gastric mucosa is seen with focal intestinal metaplasia (H\&E original magnification x100). (B) Gastric tissue with reactive mucosa showing many plasma cells and a cross section of blood vessel ( $H \& E$, original magnification $\times 400$ ). 

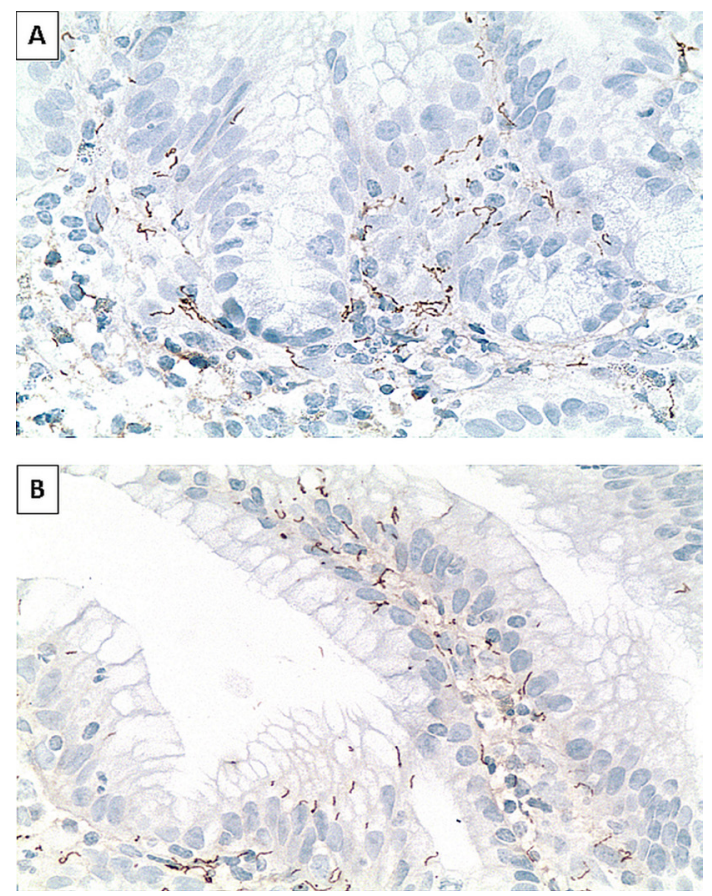

Figure 4 (A and B) Immunohistochemical staining for Treponema pallidum is positive in the lining epithelium and in the lamina propria (immunohistochemical staining, original magnification $\times 400$ ).

physicians. ${ }^{12}$ Classic symptoms include abdominal pain, nausea, vomiting or haematemesis. ${ }^{12}$ Diagnosis is usually challenging since majority of the patients do not report previous history of syphilis, and other clinical features of secondary syphilis are often absent. ${ }^{12}$ Endoscopic features include erythema, friability, nodularity, superficial ulcers and enlargement of the mucosal folds. ${ }^{3}$ Histopathology usually shows features of chronic inflammation with perivascular distribution and T. pallidum can be detected using a variety of techniques. ${ }^{12}$ Treatment with penicillin based on the clinical stage

\section{Learning points}

- Syphilitic gastritis is one of the rare manifestations of syphilis that is not well recognised by physicians.

- The majority of patients affected by syphilitic gastritis lack other signs and symptoms of syphilis and no previous history of primary infection.

- Diagnosis of syphilitic gastritis rely on the combination of history, physical, radiological, serological and pathological findings. Treatment with penicillin based on the clinical stage of syphilis is curative.

of the disease is usually followed by a complete resolution of the symptoms. ${ }^{1}$

Contributors MO carried out the literature review, wrote the initial draft of the manuscript, revised it critically, collected the images, approved the final version to be published and made sure all the information presented in the manuscript was accurate. SH: edited the manuscript, revised it critically, approved the final version to be published and made sure all the information presented in the manuscript was accurate. QA, ME and GB edited the manuscript, revised it critically, approved the final version to be published and made sure all the information presented in the manuscript was accurate.

Funding This research received no specific grant from any funding agency in the public, commercial or not-for-profit sectors.

Competing interests None declared.

Patient consent Obtained.

Provenance and peer review Not commissioned; externally peer reviewed.

(C) BMJ Publishing Group Ltd (unless otherwise stated in the text of the article) 2018. All rights reserved. No commercial use is permitted unless otherwise expressly granted.

\section{REFERENCES}

1 Hartwell JA. Syphilis of the stomach: A critical review of reported cases from the pathological and clinical viewpoints. Ann Surg 1925;81:767-90.

2 Mylona EE, Baraboutis IG, Papastamopoulos V, et al. Gastric syphilis: a systematic review of published cases of the last 50 years. Sex Transm Dis 2010:37:177-83.

3 Souza Varella Frazão M, Guimarães Vilaça T, Olavo Aragão Andrade Carneiro F, et al. Endoscopic aspects of gastric syphilis. Case Rep Med 2012:2012:1-4.

Copyright 2018 BMJ Publishing Group. All rights reserved. For permission to reuse any of this content visit http://group.bmj.com/group/rights-licensing/permissions.

BMJ Case Report Fellows may re-use this article for personal use and teaching without any further permission.

Become a Fellow of BMJ Case Reports today and you can:

- Submit as many cases as you like

- Enjoy fast sympathetic peer review and rapid publication of accepted articles

- Access all the published articles

- Re-use any of the published material for personal use and teaching without further permission

For information on Institutional Fellowships contact consortiasales@bmjgroup.com

Visit casereports.bmj.com for more articles like this and to become a Fellow 